\title{
Insurance claims in Uganda: A Critical Analysis of the Motor Vehicle Insurance (Third Party Risks) Act Cap 214
}

\author{
Ahmed Kinobe \\ Faculty of Law, Islamic University in Uganda Females Campus - Kabojja, \\ P.O Box 7724, Kampala-Uganda
}

\begin{abstract}
"Insurance is an ingenious modern game of chance in which the player is permitted to enjoy the comfortable conviction that he is beating the man who keeps the table" (Bierce, 1911)A total of 9,000 people lost their lives in road accidents in the last three years according to the recent Traffic Police reports while the 2017 Ministry of Works and Transport reported that at least 10 people die every day due to bodaboda-related accidents. Kiva $(2018$, p. 4). This is in addition to a big number of individuals who have suffered bodily injuries in road accidents and who are not usually tracked. Taking the case study of the Gaagaa bus accident which took place along Kiryandogo road, the government of Uganda compensated the families of the accident victims with shs.5,000,000/= (Five Million Uganda Shillings Only) and shs.3,000,000/= (Three Million Uganda Shillings only) for the relatives of deceased and injured victims respectively. Surprisingly, there is no indication that the motor vehicles involved in this accident were government-owned or uninsured as to entitle victims involved to compensation from the government. Besides, the amount compensated was above the statutory limit of shs.150,000/= (One Hundred and Fifty Thousand Uganda Shillings) inclusive of costs incidental to the judgment!!!The dilemma of third-party insurance compensation policy is embedded in the fact that there is a big number of victims who are not compensated as there are also many policyholders who have not benefited from the cover because they have not caused or been involved in an accident. This calls for a critical analysis of the insurance claims in Uganda in light of the Motor Vehicle Insurance (Third Party Risks) Act Cap 214 to address this injustice.This article presents the current legal framework for compensation against the insured. It analyses the challenges of insurers with the said legal framework. It recommends among others the amendment of S.39 of the Motor Vehicle Insurance (Third Party Risks) Act Cap 214 to establish a compensation policy that can benefit policyholders and to establish a Motor Insurance Information Centre which can facilitate the third-party suits against insurers.
\end{abstract}

Keywords: Third-party, Insurance, Compensation, Indemnity.

DOI: $10.7176 / \mathrm{JLPG} / 110-04$

Publication date: June $30^{\text {th }} 2021$

\section{Introduction}

Insurance is the exchange of premium for risk and the insurer undertakes to compensate the insured upon the happening of the uncertain event. The risk to the subject matter of an insurance contract is transferred from the insurer to the insured. The insured is guaranteed compensation of a specified sum of money upon the happening of a risk insured against. The maximum amount of compensation or nature of benefit varies depending on the type of insurance. Insurance is categorized into first and third-party insurance, the former insures ones' own life, house, factory, or car whereas the latter is a cover against potential liability in law to pay damages to another. Other categorizations are based on the nature of insurance e.g. Motor Vehicle Third Party insurance

The Motor vehicle Third Party insurance policy covers the death of or bodily injury to another person although it has been expanded to cover other loss or damage e.g. loss or damage to the contents of the car, destruction of or damage to the garage in which the car is kept. The scope of a motor vehicle Third Party insurance policy determines the measure of indemnity in any motor vehicle accident claim. However, the uncertainty by motorists on the extent of the cover against the third party claims questions the validity of the majority of contracts between insurers and motorists.

An insurance policy that at least covers the death of or bodily injury to another person is compulsory for all motorists except government-owned vehicles. The penalty attached to the use of a motor vehicle without an insurance policy compels compliance. However, if only the motorists believed in guaranteed compensation or loyalty payments for no-fault, insurance would be voluntary. Secondly, the conflict in the quantum of fine under the different regulatory frameworks leaves offenders at the mercy of law enforcers (police).

A third-party claim for indemnification is either against the owner, or the driver or the council for uninsured vehicles but not the insurer. However, the exclusion of the insurer from direct liability for insured motor vehicles faults the exceptions to the doctrine of privity of contract and is very restrictive.

This paper focuses on three main objectives. First, to examine the current legal framework regulating insurance claims in Uganda. Secondly, to examine the challenges faced by the current legal framework visa viz compensation claims against insurers. Lastly, to suggest the possible way forward concerning insurance claims 
in Uganda.

\section{Research Methodology}

This paper uses the doctrinal approach by analyzing statutory provisions, legal rules, principles or doctrines, and cases. Three research questions have been developed to guide in reviewing the literature. First, what is the current legal framework regulating insurance claims in Uganda? Secondly, what challenges are faced by the current legal framework visa viz compensation claims against insurers? Lastly, what is the way forward concerning insurance claims in Uganda?

\section{Literature Review}

3.1 The current legal framework regulating insurance claims in Uganda

According to Section 2 of the Motor Vehicle Insurance (Third Party Risks) Act Cap 214 except for government vehicles, it is unlawful for a person to use a vehicle without a third-party motor vehicle insurance policy. Otherwise, is liable on conviction to a fine and or imprisonment and or disqualification for holding or obtaining a driving permit. Further, under the Traffic Control and Road Safety Act Cap 361(As Amended), Section 33(1) (d) thereof creates an offence of permitting to or use of a motor vehicle, trailer, or engineering plant on the road without an insurance policy prescribed by the law punishable on conviction to a fine and or imprisonment.

It is a criminal offence to use a vehicle on the road without an insurance policy against third party risks except for government vehicles. The imposition of mandatory insurance on all vehicle users is a guarantee to other road users that in the event of an accident the victim shall be compensated.

The government vehicles are exempted from the compulsory insurance of vehicles whereas private vehicles are under an obligation to have motor vehicle third party insurance. Therefore, the exemption of government vehicles from mandatory motor vehicle third party insurance is a discriminatory law and offends the provision of the constitution of the Republic of Uganda.

Secondly, Section 3(b) of the Motor Vehicle Insurance (Third Party Risks) Act Cap 214 provides that the required insurance policy is one which insures a person against liability incurred by him or her in respect of bodily injury or death of another person not arising out of or in course of employment of the person.

The same position of the law was emphasized by Justice E. S. Lugayizi, in the case of Aqua Plumbing (U) Ltd vs. United Assurance Co. Ltd [2004] UGCOMMC 7. She dismissed the suit against the defendant for breach of insurance contract because, at the time of the contract, the plaintiff's motor vehicle had no comprehensive motor vehicle policy covering it. It was also stated that it is a legal obligation of every motor vehicle owner to possess a third party motor vehicle insurance policy to lawfully use his or her motor vehicle on the roads. A cover in respect of damage or personal injury to a third party is third party motor vehicle insurance policy. Whereas, a cover in respect of damage to the motor vehicle or another's motor vehicle or property is a comprehensive motor vehicle insurance policy. The two are essentially different. However, the latter covers the former if a motorist opts for the latter.

The minimum a policy of insurance in respect of third-party risks that complies with the requirements of Motor Vehicle Insurance (Third Party Risks) Act Cap 214 should cover is bodily injury or death of another person except that arising out of or in the course of employment of that person. The liability for personal injury or death of an employee is regulated by the Workers Compensation Act Cap 225.

A motor vehicle should possess an insurance policy against third party risk which minimally covers bodily injury or death of another person. Thus, the limitation of a motor vehicle third-party insurance policy to cover minimum liability for bodily injury or death of another person is a limited scope.

Thirdly, a third party claim for death, bodily injury, or damage to property is commenced against any of the following; owner, driver, or Nominal Defendant Council (hereinafter referred to as "Council") and not the insurer according to Section 39 of the Motor Vehicle Insurance (Third Party Risks) Act Cap 214. However, Section 35 of the same Act a claim for death or bodily injury against an owner or driver of an uninsured vehicle is made against the council as if it were the insurer under a policy of insurance. Also, under Sections 3.4 and 4.5 of the Common Market for Eastern and Southern Africa operational manual of the yellow card scheme and reinsurance pool, October 2015, accident claims as against visiting or transit vehicle in foreign jurisdictions, their court process shall be served on and the arrangement of a legal defence shall be by the handling bureau on behalf of the insured.

A similar position was maintained by Justice Christopher Madrama Izama, in the case of Katongole vs. Excel Insurance Company Ltd [2014] UGCOMMC 117, wherein he overruled a preliminary objection on the question of whether the defendant is a proper party to be sued. It is because the plaintiff's action is for breach of contract concerning documents that were turned down by the National Bureau of Rwanda for inaccuracies in their claim for indemnity concerning accidents involving PTA yellow cardholders. It follows, therefore, that if all the documentation were proper and the claim was for indemnity, the court process would be as against the National Bureau of Rwanda, not the insurer (Excel Insurance Company Ltd). 
A claim for indemnity can only be made against the owner of the vehicle, driver of the vehicle, Council, or Bureau. A claim is made against Council for an uninsured vehicle whereas against the Bureau for vehicles in transit or visiting a foreign jurisdiction. Otherwise, such an action would not be proper before a court.

A third party cannot claim from the insurer damage to personal property, bodily injury, or death of any person arising from the accident. However, the Council settles claims against an owner or driver of the uninsured vehicle resulting in death or bodily injury as if it were the insurer. Therefore, if an action can be brought against the Council as if it were the insurer, there is no reason for the bar of direct suits against the insurer for insured vehicles.

Fourthly, according to Section 41(2)(b) of the Motor Vehicle Insurance (Third Party Risks) Act Cap 214 the Minister shall make regulations prescribing the minimum amount to be insured relating to liability under an insurance policy after consulting the Uganda Insurance Association. In furtherance of the same, Regulation 4 of the Motor Vehicle Insurance (Third Party Risks) Regulations Statutory Instrument 214-1 provides that the maximum liability of an insurer per policy is shs.1,000,000/= per person per accident and the maximum aggregate liability per accident is shs.10,000,000/=. Also, under Section 34 of the Motor Vehicle Insurance (Third Party Risks) Act Cap 214 the liability of the council is limited to shs.150,000/= including costs connected to the judgment or an amount higher prescribed by the Minister in the statutory instrument.

Salmon $(2019$, p. 27), explains that the limit for statutory Motor Third Party insurance only covers bodily injury and or death up to shs.1,000,000/= per person and shs.10,000,000/= in an accident involving many people. He further adds that however, third party comprehensive vehicle insurance covers both third party liabilities as well as any damage risk to the insured's vehicle. The payments under third party comprehensive vehicle insurance are shs.5,000,000/= and above whereas in an aggregate event with many people is shs. $50,000,000 /=$.

Justice Steven Musota, in the case of National Insurance Corporation Ltd vs. Kakugu [2016] UGHCCD 136, dismissed the appeal against the decision of the lower court that found that the appellant breached the insurance contract thereby ordering the respondent to pay a total sum of shs.7,480,000/= as compensation plus shs.3,000,000/= as general damages and costs of the suit. The reason for the decision is that the misrepresentation and non-disclosure complained of did not induce the appellant to give the policy. Therefore, the appellant is liable to indemnify the respondent for the loss of the motor vehicle registration number UDN 414M.

The maximum liability of an insurer per accident is shs. $150,000 /=, 1,000,000 /=$, and shs. $10,000,000 /=$ for uninsured vehicles, per person per policy and maximum agreement per policy respectively.

Section 34 of the Motor Vehicle Insurance (Third Party Risks) Act Cap 214 and regulation 4 of the Motor Vehicle Insurance (Third Party Risks) Regulations Statutory Instrument 214-1 only provides for a maximum liability of an insurer per policy per accident without a minimum liability of an insurer per policy per accident. It is implied that the provisions were intended to protect the insurer, not the insured. Hence, section 34 of the Motor Vehicle Insurance (Third Party Risks) Act Cap 214 and regulation 4 of the Motor Vehicle Insurance (Third Party Risks) Regulations Statutory Instrument 214-1 are unjust.

Lastly, Bakibinga (2013, p. 154), discusses the background and rationale of the doctrine of privity. The rule of privity of contract is that no one has a right to benefit from the terms of a contract to which he is not an original party. A third party at common law has no claim over an insurance policy that confers a benefit to him or her.

Section 65(1) of the Contracts Act No. 07 of 2010 stipulates that a person not a party to a contract may in his or her right enforce a term of a contract, if the contract expressly states so or if a term of the contract confers a benefit on that person. Further, subsection 2 provides that the right to enforce a term of the contract that confers a benefit on a third party depends on the interpretation that the parties intended the term to be enforced by that party.

Justice Hellen Obura, in the case of Uganda South Sudan Grain Traders and Suppliers Association Ltd vs. The Government of the Republic of South Sudan [2013] UGCOMM 53, dismissed the application for a declaration that the respondent's refusal of performing its commitment under the Memorandum of Understanding (MOU) between it and the Republic of Uganda for the benefit of the applicant as an infringement of the applicant's right to property. The application was dismissed because the MOU between the Republic of Uganda and the respondent although it was for the benefit of the applicant it was not intended under the MOU that the applicant would enforce the MOU in the courts of law.

The general rule is that a stranger to a contract cannot enforce the said contract except if the third party is a beneficiary to a contract. However, it is subject to the construction of the terms of the contract conferring benefit to the third party to infer the intention of its enforcement by a third party.

The enforcement of terms of a contract by a beneficiary is an exception to the general rule that a third party cannot enforce terms of a contract is not a party. However, the requirement of intention construed from the terms of the contract impedes benefiting from the exceptions to the privity doctrine. 
3.2 The challenges faced by the current legal framework visa vie compensation claims against insurers.

First, section 2(3) of the Motor Vehicle Insurance (Third Party Risks) Act Cap 214 stipulates that the use of a vehicle without an insurance policy against third party risks is an offence and a person is liable on conviction to either a fine not exceeding shs.100,000/= or a term of imprisonment not exceeding 2 years or to both.

Similarly, under section 33(1) (d) and First Schedule of the Traffic and Road Safety Act Cap 361 (As Amended), it states that the use of a motor vehicle, trailer, or engineering plant without any insurance prescribed by the law for that use, is an offence punishable by a fine of not less than 10 currency points and not exceeding 40 currency points or imprisonment of not less than 1 year and not exceeding 2 years or both. A currency point is equivalent to shs. $20,000 /=$ i.e. the fine is between shs. $200,000 /=$ and shs. $800,000 /=$.

The fine stated by the Motor Vehicle Insurance (Third Party Risks) Act Cap 214 is below the minimum fine prescribed by the Traffic and Road Safety Act Cap 361 (As Amended) and the reverse is true. Therefore, the Traffic and Road Safety Act Cap 361 (As Amended) contradicts the Motor Vehicle Insurance (Third Party Risks) Act Cap 214 as to the fine on the use of a motor vehicle without an insurance policy against third party risks.

Secondly, Mckendrick (2009, p. 110), discussed the doctrine of privity of contract, in one of its principles to mean that a third party cannot sue for an entitlement to a promised performance despite being contracted to benefit him or her.

However, Section 65(1) of the Contracts Act No. 07 of 2010 stipulates that a person not a party to a contract may in his or her right enforce a term of a contract, if the contract expressly states so or if a term of the contract confers a benefit on that person. Further, subsection 2 provides that the right to enforce a term of the contract that confers a benefit on a third party depends on the interpretation that the parties intended the term to be enforced by that party.

A contract of insurance is a contract of indemnity. Section 68 of the Contract's Act No. 7 of 2010 defines a contract of indemnity as an agreement where one party promises another to save him or her from any loss caused to them by the conduct of another person. But under section 69 of the same Act, it is only a promisee entitled to recover from the promisor for any damages, cost, or sums of money. The same is the position under Section 39 of Motor Vehicle Insurance (Third Party Risks) Act Cap 214 which provides that any liability for damage to property, death, or injury, a third party shall claim against the owner, driver, or council but not the insurer.

However, Justice David Wangutusi, in Asante Aviation Ltd vs. Star of Africa Air Charters Ltd \& 3 Ors. [2017] UGCOMMC 125 was of a different view and found that the defendant or counterclaimant could rightly be sued by the $2^{\text {nd }}$ Counter Defendant although she is not privy to the contract between the $1^{\text {st }}$ and $2^{\text {nd }}$ Counter Defendants. The position of the law is that a third party cannot sue those that have entered into their contract because it does not have a that close, mutual, or successive relationship to the same rights of property or power to enforce a term in the agreement. However, the practice is that a person not privy to a contract can sue on condition that the contracting parties intended the third party to derive benefit from their contract. The assurance that the payments were made for the benefit of the Counterclaimant entitles the Counterclaimant to sue the $2^{\text {nd }}$ Counter Defendant.

A motor vehicle insurance policy is taken out against third party risks. However, a third party cannot enforce a term contracted to benefit him or her except if the term confers upon that party a right to enforce it. Therefore, Section 65(1) of the Contract's Act No. 7 of 2010 contradicts section 65(2) of the same Act whereas section 39 of the Motor Vehicle Insurance (Third Party Risks) Act Cap 214 contradicts section 2 of the same Act.

Thirdly, section 10(2) of the Contract's Act No. 7 of 2010 defines a contract as an agreement entered with the free consent of the parties with the capacity to contract, for a lawful consideration, with a lawful object, and with the intention to be legally bound. Section 13 of the same Act describes what amounts to free consent of the parties as that that is not caused by any of the following; coercion, or undue influence, fraud, misrepresentation, or mistake.

However, section 2(1) Motor Vehicle Insurance (Third Party Risks) Act Cap 214 states with emphasis that it "shall" not be lawful for a person to use a vehicle without a third-party risk insurance policy.

A similar position was resounded by Justice E. S. Lugayizi, in the case of Aqua Plumbing (U) Ltd vs. United Assurance Co. Ltd [2004] UGCOMMC 7 that it is a legal obligation of every motor vehicle owner to possess a third party motor vehicle insurance policy to lawfully use his or her motor vehicle on the roads.

A contract to which a motor vehicle insurance third party risks policy is an example must be entered without coercion, with the capacity to contract, for lawful consideration, with a lawful object, and with the intention to be legally bound. However, possession of a third party motor vehicle insurance policy is a statutory duty compelled by law.

The lawful use of a motor vehicle on the road requires possession of an insurance policy against third party risks. An insurance policy against third party risks is a contract that should be entered without coercion among others. Therefore, the legal obligation of every motor vehicle owner to possess a third party motor vehicle insurance policy detracts it from its voluntariness in contract formation. 


\section{Discussion}

First, the exemption of government vehicles from mandatory motor vehicle third party insurance is a discriminatory law and offends the constitution of the Republic of Uganda.

Section 2(1) and (2) of the Motor Vehicle Insurance (Third Party Risks) Act Cap 214 provides that except for government vehicles, it is unlawful for a person to use a vehicle without a third-party motor vehicle insurance policy. However, article 21(1) of the Constitution of the Republic of Uganda 1995 stipulates that all persons are equal before and under the law in all spheres and respect and shall enjoy equal protection of the law.

Justice A.E.N. Mpagi - Bahigeini, in the case of Attorney General vs. Osotraco Ltd [2005] UGCA 1, dismissed the appeal that challenged the decision of the trial court that granted an order of eviction against the government in contravention of s.15(1)(b) (now s.14(1)(b)) of the Government Proceedings Act which is to the effect that court shall make orders appropriate in proceedings between private persons except that in proceedings against government court shall not make any order for recovery of land or delivery of property but make declaratory orders of the same. It is because the law has to be construed in line with the thinking or norms of progressive societies. The constitution is primary to all laws, the historic common law doctrines restricting the liability of the state should not be allowed to obstruct constitutional protection of fundamental rights. The judge at appeal agreed with the findings of the trial judge that section 15(1) (b) of the Government Proceedings Act that compels a court to provide only a declaratory relief which is not an effective remedy is not in conformity with the constitution. The trial judge found that the provision is not applicable in the circumstances by applying qualifications to it required under article 274 of the constitution that calls for the construction of existing laws after the coming into force of the constitution with such modifications and qualifications to bring them in conformity with the constitution. He accordingly made an order of vacant possession within 30 days of failure of which eviction issues.

Since it is unlawful for a person to use a motor vehicle without an insurance policy against third party risks except for the government. But all persons are equal before and under the law and enjoy equal protection of the law. Therefore, section 2(1) and (2) of the Motor Vehicle Insurance (Third Party Risks) Act Cap 214 violates article 21(1) of the Constitution of the Republic of Uganda, 1995.

Secondly, the limitation of a motor vehicle third-party insurance policy to cover minimum liability for bodily injury or death of another person is a limited scope.

According to Section 3(b) of the Motor Vehicle Insurance (Third Party Risks) Act Cap 214 an insurance policy that is by law required is one which insures a person against liability incurred by him or her in respect of bodily injury or death of another person not arising out of or in course of employment of the person.

The compensation of shs. $1,000,000 /=$ to a third party upon being involved in an accident on Boda Boda is very little. Mukhaye $(2020$, p. 3$)$ It is because the law does not cover the person and the motorcycle. Therefore, the 2015 proposed amendment be revised to cover people, motorcycles, and taxis and save their businesses even when they die.

In Great Britain, third party risk insures against liability in respect of death or bodily injury to any person or damages to the property caused by or arising out the use of the vehicle on a road or public place. Birds (2013, p. 409) Furthermore, a modern motor vehicle policy against third party risks is one that covers the following; litigation costs, injury or death to or of the assured, loss or damage to the vehicle or contents of the car, destruction of or damage to the garage in which the car is kept, and the cost of hire. Legh-Jones et al (2008, p. 29)

Uganda's law on the Motor Vehicle Insurance (Third Party Risks) is limited to bodily injury or death liabilities of another person. However, the modern law on third party risk policy extends to litigation costs, loss or damage to the vehicle or contents of the car, and destruction of the vehicle. Thus, Motor Vehicle Insurance (Third Party Risks) Act Cap 214 is not in touch with the realities of life today.

Thirdly, the liability for damage to property, death, or injury cannot be enforced by a third party.

Section 2 of the Motor Vehicle Insurance (Third Party Risks) Act Cap 214 states that except for government vehicles, it is unlawful for a person to use a vehicle without a third party motor vehicle insurance policy. However, section 39 of the same Act stipulates that a third party shall claim liability for damage to property, death, or injury, against the owner, driver, or council but not the insurer.

Similarly, in a contract of indemnity, it is only a promisee entitled to recover from the promisor for any damages, costs, or sums of money as provided for under section 69 of the Contract's Act No. 7 of 2010.

A person not a party to a contract may in his or her right enforce a term of a contract, if the contract expressly states so or if a term of the contract confers a benefit on that person according to section $65(1)$ of the Contracts Act No. 07 of 2010. But, the right to enforce a term of the contract that confers a benefit on a third party depends on the interpretation that the parties intended the term to be enforced by that party also according to section $65(2)$ of the same Act.

$95.3 \%$ of motorists do not know their rights and $87.8 \%$ of motorists do not know their obligations when involved in an accident. (Kitunzi et al, 2016) As a result, the majority of motorists involved in accidents do not make claims to their insurers for compensation. 
A third party has a right to enforce a contract with a term that confers a benefit on him or her. As long as the term is construed to appear that the parties intended the term to be enforced by a third party. It is because a third party shall claim liability for damage to property, death, or injury, against the owner, driver, or council but not the insurer. The statute implies a term in a Motor Vehicle Insurance (Third Party Risks) contract that a victim cannot enforce the said contract. Hence, the pre-condition of the right of a third party to enforce a contract that benefits him or her on the interpretation of the term to appear that the parties intended the term to be enforced by a third party is a clog on the entitlement and the exceptions to the privity doctrine.

Fourthly, regulation 4 of the Motor Vehicle Insurance (Third Party Risks) Regulations Statutory Instrument 214-1 is unconstitutional, null and void because it contravenes Article 20 and 21(1) of the Constitution of the Republic of Uganda, 1995.

Regulation 4 of the Motor Vehicle Insurance (Third Party Risks) Regulations Statutory Instrument 214-1 provides that the maximum liability of an insurer per policy is shs.1,000,000/= per person per accident and the maximum aggregate liability per accident in shs. $10,000,000 /=$.

Article 20 of the Constitution of the Republic of Uganda, 1995 stipulates that the fundamental rights and freedoms of individuals are inherent, not granted by the state, and shall be respected, upheld, and promoted by all organs and agencies of government and by all persons. Further article 21(1) thereof stipulates that all persons are equal before and under the law in all spheres of political, economic, social, and cultural life and every other respect and shall enjoy equal protection of the law.

The constitutional court in the case of Law and Advocacy for Women in Uganda vs. Attorney General [2007] UGCC 1, declared section 154 of the Penal Code Act Cap 120 unconstitutional, null and void because it was inconsistent with article 20, 21 (1), (2) and (3), 24, 31 (1), 33 (6) of the Constitution of the Republic of Uganda, 1995. Under section 154 of the Penal Code Act Cap 120, a married man would not be liable for the offence of adultery if sexual intercourse is with an unmarried woman. Since the reverse was not true for a married woman section 154 of the Penal Code Act was found to be degrading and undermines the status of women.

Regulation 4 of the Motor Vehicle Insurance (Third Party Risks) Regulations Statutory Instrument 214-1 only provides for the maximum liability of an insurer in a policy. All persons regardless of their differences must have equal protection of the law. For the reason that regulation 4 of the Motor Vehicle Insurance (Third Party Risks) Regulations Statutory Instrument 214-1 provides for a maximum liability of an insurer without minimum indemnity for the insured, it does not provide equal protection to both the insurer and insured. Therefore, it is unconstitutional, null, and void.

Fifthly, there is a conflict in the purnishment of the fine prescribed by the Motor Vehicle Insurance (Third Party Risks) Act Cap 214 as well as the Traffic and Road Safety Act Cap 361 (As Amended). The imposition of the fine prescribed by the Traffic and Road Safety Act Cap 361 (As Amended) would be greater than the maximum penalty prescribed by the Motor Vehicle Insurance (Third Party Risks) Act Cap 214.

Section 2(3) of the Motor Vehicle Insurance (Third Party Risks) Act Cap 214 stipulates that the use of a vehicle without an insurance policy against third party risks is an offence and a person is liable on conviction to either a fine not exceeding shs.100,000/= or a term of imprisonment not exceeding 2 years or to both.

Similarly, under section 33(1) (d) and the First Schedule of the Traffic and Road Safety Act Cap 361 (As Amended), state that the use of a motor vehicle, trailer, or engineering plant without any insurance prescribed by the law for that use, is an offence punishable by a fine of not less than 10 currency points and not exceeding 40 currency points or imprisonment of not less than 1 year and not exceeding 2 years or both. A currency point is equivalent to shs.20,000/= i.e. the fine is between shs.200,000/= and shs.800,000/=.

The Motor Vehicle Insurance (Third Party Risks) Act Cap 214 penalizes the use of a motor vehicle without an insurance policy to a fine not exceeding shs.100,000/= whereas the Traffic and Road Safety Act Cap 361 (As Amended) penalizes a similar act with a fine between shs. $200,000 /=$ and shs. $800,000 /=$. Hence, there is a conflict between the Traffic and Road Safety Act Cap 361 (As Amended) and the Motor Vehicle Insurance (Third Party Risks) Act Cap 214.

Sixthly, the creation of the offence of driving a motor vehicle without insurance policy against third party risks is a threat intended to cause motorists to enter into insurance contracts. Therefore, the contract between the insurer and insured for an insurance policy against third party risk is entered without free consent.

Section 10(2) of the Contract's Act No. 7 of 2010 defines a contract as an agreement entered with the free consent of the parties, with the capacity to contract, for a lawful consideration, with a lawful object, and with the intention to be legally bound. Section 13 of the same Act describes what amounts to free consent of the parties as that that is not caused by any of the following; coercion, or undue influence, fraud, misrepresentation, or mistake. However, section 2(1) Motor Vehicle Insurance (Third Party Risks) Act Cap 214 states with emphasis that it "shall" not be lawful for a person to use a vehicle without a third-party risk insurance policy.

Consequently, under section 16(1) of the Contract's Act No. 7 of 2010, a contract is voidable at the option of a party whose consent was obtained by coercion, undue influence, fraud, or misrepresentation. A voidable contract is an agreement which is enforceable by law at the option of a party to a contract but not at the option of 
the other part as per section 2 of the same Act.

All motorists must have an insurance policy against third party risks. Yet a third party risks insurance policy is a contract that should be entered with the free consent of the parties. Otherwise, the third party risks insurance policy stands to be enforceable only at the option of the insured. Thus, a motor vehicle third party insurance policy required by the Traffic and Road Safety Act Cap 361 (As Amended) and the Motor Vehicle Insurance (Third Party Risks) Act Cap 214 is a voidable agreement.

Lastly, an insured faithfully takes out an insurance policy against third party risks every year but he or she does not incur any liabilities against third parties during the period of the cover. Others do incur liabilities but amicably settle with third parties and never claim from their insurers. Since the insured has not claimed from the insurer in the period covered, therefore, it is fair that the insured is entitled to no claims and loyalty bonuses for the faultless period of insurance.

The no-claims bonus is an arrangement that provides the insured with a particular diminution on the premium of the subsequent year if no claim is made in the previous year. Birds $(2013, \mathrm{p}$. 408) In the motor insurance market in the United Kingdom, motorists earn a bonus year every year without a claim to a maximum period of four years and lose two bonus years for every fault. Bland (1996, p. 445) However, the enforcement of legal entitlement to motor policy bonuses is difficult because every renewal is a separate contract.

The premium paid for an insurance policy against third party risks would be sufficient to cover the insured if not at fault the previous year to a subsequent year of cover as a bonus. But such a contract of insurance is terminated by expiry that year and is unenforceable in the subsequent year.

Therefore, a motorist should be entitled to a cash bonus for a faultless period of insurance since the insured has not made any fault claims.

\section{Conclusion}

a. Section 2(1) and (2) of the Motor Vehicle Insurance (Third Party Risks) Act Cap 214 contravenes article 21(1) of the Constitution of the Republic of Uganda, 1995, and is therefore unconstitutional.

b. The scope of the motor vehicle insurance policy against third party risks to cover only the bodily injury or death of another person is small.

c. Although a third party cannot enforce an agreement that was contracted to benefit him or her. But the absence of a database register of all motor vehicles and their respective insurers that is kept annually would hinder the enforcement of motor vehicle third party insurance claims by third parties if it was permitted by the law.

d. Regulation 4 of the Motor Vehicle Insurance (Third Party Risks) Regulations Statutory Instrument 214-1 infringes on article 21(1) of the Constitution of the Republic of Uganda, 1995. Hence, it is unconstitutional.

e. Section 33(1) (d) and the First Schedule of the Traffic and Road Safety Act Cap 361 (As Amended) contradicts section 2(3) of the Motor Vehicle Insurance (Third Party Risks) Act Cap 214.

f. The contract of insurance according to the Motor Vehicle Insurance (Third Party Risks) Act Cap 214 is voidable at the option of the insured.

g. The insured does not benefit from a faultless period of insurance and he or she is expected to renew his or her insurance policy the subsequent year.

\section{Recommendations}

I. Amendment of section 2(1) and (2) of the Motor Vehicle Insurance (Third Party Risks) Act Cap 214 by repealing section 2(2) of the principal Act.

II. Amendment of section 3(b) of the Motor Vehicle Insurance (Third Party Risks) Act Cap 214 by including insurance of a person in respect of liability which may be incurred in respect of damage to a motor vehicle of another.

III. Amendment of section 65(1) of the Contracts Act No. 07 of 2010 by repealing subsection 2 thereof. To amend section 39 of the Motor Vehicle Insurance (Third Party Risks) Act Cap 214 by substituting the words "and not" with the word "or". To permit claims against insurers by third parties. Further, to establish a Motor Insurers' Information Centre that keeps the name and address of an insurer and the number of the insurance policy for every motor vehicle, to assists victims to seek compensation.

IV. Amendment of regulation 4 of the Motor Vehicle Insurance (Third Party Risks) Regulations Statutory Instrument 214-1 by including minimum limits of liability per person and minimum aggregate per accident.

V. Amendment section 2(3) of the Motor Vehicle Insurance (Third Party Risks) Act Cap 214 by substituting shs. $100,000 /=$ with shs. $800,000 /=$.

VI. Amendment of section 2(1) Motor Vehicle Insurance (Third Party Risks) Act Cap 214 by removing the word "shall".

VII. To make legislation to provide for an automatic discount given upon renewal of the contract in place of the no claims bonus in circumstances of a faultless period of motor vehicle insurance policy. 


\section{References}

Bakibinga, D J 2013, Law of Contract in Uganda. $2^{\text {nd }}$ ed, The Written Word Publications, Kampala.

Bierce, A 1911. The Devil's Dictionary. [Online] Available at: http://www.pinterest.com [Accessed Saturday, July 2020].

Birds, J 2013, Birds' Modern Insurance Law, $9^{\text {th }}$ ed, Sweet \& Maxwell, London.

Bland, R 1996, The future of no claims bonus, General Insurance Convention.

Kitunzi, H., Mirembe, H. and Guma, C 2016, Influence of awareness on the usage of motor third party insurance: a case study of Kampala district. African Health Sciences, 16(4), pp. 1170 -1173.

Legh-Jones, N., Birds, J. and Owen, D 2008, MacGillivray on Insurance Law, $11^{\text {th }}$ ed, Sweet \& Maxwell, London.

Mckendrick, E 2009, Contract Law, $8^{\text {th }}$ ed, Palgrave Macmillan, London.

Mukhaye, D 2020, Government body calls for compulsory insurance of schools, Bodabodas, Nation Media Group PLC, Kampala.

Nelson, K 2018, Govt sued over motor vehicle third party insurance, New Vision Printing \& Publishing Company Limited (NVPPCL), Kampala.

Salmon, J 2019, Motor third party insurance policies: What they cover, cost, Nation Media Group PLC, Kampala. 